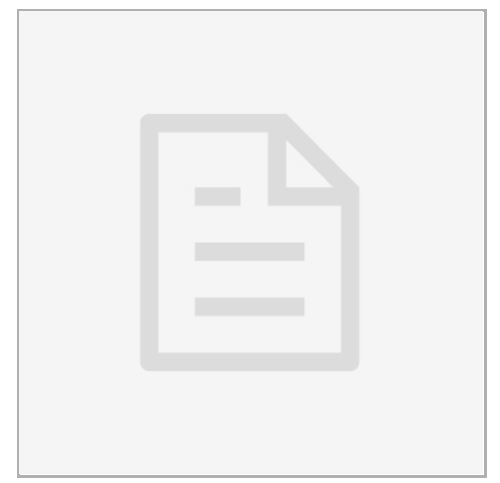

VERSION 2

NOV 21, 2020

open $\odot$ access

DOI:

dx.doi.org/10.17504/protocol s.io.bpxzmpp6

Protocol Citation: Marco Cosentino, Elisa Storelli, Alessandra Luini, Massimiliano LM Legnaro, Emanuela Rasini, Marco Ferrari, Franca Marino 2020. PMN- 02 - MTT Assay in Human PMN. protocols.io https://dx.doi.org/10.17504/p rotocols.io.bpxzmpp6Version created by Farmacologia Medica

License: This is an open access protocol distributed under the terms of the Creative Commons Attribution License, which permits unrestricted use, distribution, and reproduction in any medium, provided the original author and source are credited

Protocol status: Working We use this protocol and it's working

Created: Nov 21, 2020

Last Modified: Nov 21, 2020

\section{(3) PMN- 02 - MTT Assay in Human PMN V.2}

Marco Cosentino ${ }^{1}, \quad$ Elisa Storelli ${ }^{1}$, Alessandra Luini $^{1}$, Massimiliano LM Legnaro ${ }^{1}$, Emanuela Rasini ${ }^{1}$, Marco Ferrari $^{1}$, Franca Marino ${ }^{1}$

\section{${ }^{1}$ Center for Research in Medical Pharmacology, University of Insubria} (Varese, Italy)

Farmacologia Medica

\section{ABSTRACT}

Published work using this protocol:

\section{- A Novel Standardized Cannabis sativa L. Extract and Its Constituent Cannabidiol Inhibit Human Polymorphonuclear Leukocyte Functions.} Mabou Tagne A, Marino F, Legnaro M, Luini A, Pacchetti B, Cosentino M.Int J Mol Sci. 2019 Apr 13;20(8):1833. doi: 10.3390/ijms20081833

\section{MATERIALS}

MATERIALS

88 Dimethyl sulfoxide (DMSO) Sigma Aldrich Catalog \#276855

$\$ 8$ Fetal Bovine Serum (FBS) EuroClone Catalog \#ECS0180L-500 ml

88 RPMI 1640 EuroClone Catalog \#ECM 0495L- 500 ml

88 Thiazolyl blue tetrazolium bromide (MTT) Sigma Aldrich Catalog \#M5655

88 Penicillin/Streptomycin EuroClone Catalog \#ECB3001D - $100 \mathrm{ml}$

Instrumentation needed:

Sterile and non sterile plastic disposables

ELISA plate reader

\section{BEFORE START INSTRUCTIONS}

Use all reagents at Room Temeperature

PROTOCOL integer ID:

44761 
1 Isolate PMN according to the protocol PMN-01a for buffy coats or PMN-01b for fresh whole blood.

2 Resuspend PMN at $1 \times 10^{6}$ cells/ml in RPMI 1640 medium supplemented with $10 \%$ Fetal Bovine Serum (FBS) and 1\% penicillin/streptomycin (SOLUTION- 13).

\section{Document}

\section{NAME}

SOLUTION- 13 - Complete culture medium

CREATED BY

Farmacologia Medica

3 Add $\ 250 \mu \mathrm{L}$ of cell suspension per well in a 96-well round bottom plate and incubate for (3) 24:00:00 alone or in the presence of the test substance at $87^{\circ} \mathrm{C}$ in a $5 \% \mathrm{CO}_{2}$ atmosphere. Cells must be plated in duplicate for each experimental condition.

4 Centrifuge at $\because 1400 \times \mathrm{g}, 00: 05: 00$ and discard the supernatant.

\section{Equipment}

Allegra AVANTI 30

Centrifuge

Beckman Coulter

Beckman Italy

5 Resuspend cells with $\triangle 200 \mu \mathrm{L}$ of MTT solution at $\mathbf{0 . 5} \mathbf{~ m g / m I}$, incubate for 02:00:00 at 
$8^{\circ} 37^{\circ} \mathrm{C}$ in a $5 \% \mathrm{CO}_{2}$ atmosphere.

6 Centrifuge at $\because 1400 \times \mathrm{g}, 00: 05: 00$ and discard the supernatant.

\section{Equipment}

Allegra AVANTI 30

NAME

Centrifuge

TYPE

Beckman Coulter

BRAND

Beckman Italy

SKU

7 Add $\triangle 120 \mu \mathrm{L}$ of DMSO per well, mix the plate until the formazan crystals are dissolved.

8 Read the plate on the ELISA plate reader at $570 \mathrm{~nm}$. 